\title{
Chapter 1. The Austronesians in History: Common Origins and Diverse Transformations
}

\author{
Peter Bellwood， James J. Fox and Darrell Tryon
}

The Austronesian languages form a single and relatively close-knit family, similar in its degree of internal diversity and time depth to other major language families such as Austroasiatic, Uto-Aztecan and Indo-European. Prior to AD 1500 the Austronesian languages belonged to the most widespread language family in the world, with a distribution extending more than half way around the globe from Madagascar to Easter Island. Today, Austronesian-speaking peoples comprise most or all of the indigenous populations of Indonesia, Malaysia, the Philippines and Madagascar. Austronesian languages are also found on Taiwan (the possible homeland of the first Austronesians), in parts of southern Vietnam and Cambodia, in the Mergui Archipelago off the coast of Burma, and on Hainan Island in southern China. Further to the east, Austronesian languages are spoken in some of the coastal areas of Papua New Guinea, in New Britain and New Ireland, and down the Melanesian chain of islands through the Solomon Islands and Vanuatu as far as New Caledonia and Fiji. From there they extend eastwards to include all of the languages of Polynesia and northwards to take in all of the languages of Micronesia.

There are estimated to be between 1000 and 1200 distinct Austronesian languages, depending on one's criteria for distinguishing languages from dialects. These languages are spoken by an estimated 270 million people whose distribution is spectacularly uneven. All but about two million Austronesian-speakers live west of a line drawn north-south at about $130^{\circ}$ east longitude, extending from just west of the Caroline Islands to just east of the Bird's Head on the island of New Guinea. The distribution of these languages over the Austronesian-speaking area is, however, relatively more even, with something over 500 languages on either side of the $130^{\circ}$ east longitudinal dividing line.

\section{Austronesian Languages as Witnesses for Cultural and Biological Ancestry at the Population Level}

The fact that so many people should speak related Austronesian languages is interesting, but does this linguistic fact illuminate the overall cultural and biological origins and histories of these populations in any useful way? After all, the peoples who speak these languages today are not identical in physical 
appearance. One would have little difficulty, for instance, in differentiating by simple visual means amongst a random mixture of Austronesian-speaking individuals of Punan (Borneo), Agta (Luzon), Fijian and Tahitian origin. Similarly, the forest-collecting Punan, the urbanized Moslem Malays of Kuala Lumpur and the atoll dwellers of Micronesia would appear to have rather little in common in the socio-economic and religious senses. Culture and physical appearance might appear to be utilized as channels of ethnic identity in many individual modern societies, yet such channels are not rigid and inflexible. Even the most cursory observation of present-day societies anywhere in the world will leave little doubt that people, often large groups of them, can intermarry with people of different biological and cultural backgrounds, change their languages, or adopt new cultures and lifestyles when conditions persuade or permit.

Yet by no means all people or societies have, by choice or obligation (excluding such extreme situations as forced population movement and slavery), undergone such fundamental transitions to any marked degree. Clearly, the vast majority of individuals in most societies, in the past perhaps much more so than in the present, have ended their lives in much the same cultural mould as they began, marrying a spouse and producing offspring very similar in physical appearance and cultural background to themselves. In some societies such relative "conservatism" would appear to have dominated through history, whereas in others there have been stronger pressures to mix with other populations and to create new biological and cultural expressions.

Austronesian societies, likewise, have varied greatly in these regards in the past. Yet for all of them there exist linguistic, biological and archaeological evidence that indicate varying degrees of common origin traceable back for a time depth of perhaps 6000 years. Austronesian societies have obviously fissioned and diversified in complex ways, and this is one of the reasons why the study of these societies of Southeast Asia and Oceania, past and present, can be so intriguing and rewarding.

Sceptics ${ }^{1}$ might question whether any shared ancestry in the cultural and biological senses is really implied for the 270 million people who speak Austronesian languages today. This question is hard to answer in any absolute way since every Austronesian society has a different history and it would be futile and divisive to allocate degrees of inherited "Austronesian-ness". But one must surely reject any explanation for the Austronesian languages that would see them as spread ancestrally by borrowing or by convergence amongst static pre-existing populations. In other words, unmoving peoples, already highly diversified, did not simply "borrow" Austronesian languages from one another, even though instances of such transmission have probably occurred, especially in western Melanesia. Had all the Austronesian languages spread only by such means we would hardly expect to find the remarkably unbroken and enclave-free 
distribution pattern, relatively free of diverse substratum linguistic phenomena, which exists today in virtually all regions apart from western Melanesia and the Southeast Asian mainland.

The whole picture makes sense, and obviously so for the far-flung islands of the Pacific and Madagascar, if one accepts that the ancestral versions of the modern Austronesian languages were spread mainly by colonizing speakers. There might have been occasional exceptions to this process of spread by colonization, as we can see in the recent spreads of modern national languages such as Malay and Bahasa Indonesia. But on a whole-language-family scale with both great extent and time-depth, no other explanation apart from spread by colonization makes sense.

While the principal justification for the common Austronesian heritage is linguistic, we can also see surviving threads, despite millennia of interaction and change, in the biological and cultural arenas. For instance, the vast majority of Austronesian speakers outside Melanesia and parts of the Philippines are of "Southern Mongoloid" (or Southeast Asian) biological affiliation. Some degree of common heritage is (or was in pre-modern times) also visible in the widespread occurrence of specific cultural characteristics such as tattooing, use of outriggers on canoes, features of ethnographic and prehistoric art styles, and social characteristics such as concern with birth order of siblings and a reverence for ancestral kin group founders. Generally, however, there is little which can be characterized as exclusively or uniquely Austronesian held widely today in common across all Austronesian-speaking regions, and neither should we expect such a circumstance. We see everywhere the results of innumerable diverse transformations. The themes of this book are thus partially bipartite, focusing on shared ancestry on the one hand, and culture- and region-specific transformations on the other.

\section{The Austronesians as a Phylogenetic Unit}

In order better to conceptualize aspects of shared ancestry and subsequent divergence amongst the populations within a major ethnolinguistic grouping it is appropriate to introduce here the concept of the "phylogenetic unit". This concept has been applied recently to one branch of the Austronesians, namely the Polynesians, by Kirch and Green (1987). It can also be applied carefully to the Austronesians as a whole, albeit on a much larger scale in both time and space. $^{2}$ Basically, the idea of phylogenetic relationship revolves around derivation from a common source, in cultural terms identifiable through shared patterns of language and society, in biological terms identifiable through shared configurations of the gene pool. Phylogenetic units, whether defined culturally or biologically, are subject to divergence or radiation of their internal elements through the operation of processes such as population fission with subsequent geographical separation, founder or bottleneck effects, selective adaptations to 
differing or changing environments, and the effects of contact with external societies.

Identifying Austronesian societies as members of an Austronesian phylogenetic unit in the broad sense does not imply that they belong, past and present, to a kind of sealed species-like entity with sharp and unbreachable boundaries. They do not, any more than do speakers of any other family of languages. We see the undeniable significance in many times and places of interaction between Austronesians and various non-Austronesian populations, not only in language but also in biology and other aspects of society. The reality of the past 5000 years of Austronesian prehistory and history reflects both "bifurcative" and "rhizotic" (or reticulate) processes of cultural change in the terminology favoured by Moore (1994).

It should be clear, therefore, that in order to approach questions of Austronesian history and common ancestry in the broad sense we need to keep separate, for heuristic purposes, biology, language and culture, even though many aspects of culture are inextricably linked to language. Languages, populations and cultures evolve, diversify and mix through different, albeit conceptually overlapping, mechanisms. When considering something on the whole Austronesian scale it would be naïve to assume that linguistic, cultural and biological entities and their boundaries must correlate precisely, or will ever have done so in any absolute way, although relatively high degrees of coordination and correlation, despite variations, are an essential part of the concept of a phylogenetic unit.

One of the main implications of this book is therefore that Austronesian peoples and societies are all linked by branching but not sealed lines of common ancestry spanning the past 6000 years or so. But anyone inquisitive about the nature of the human species might wish to ask why such a unit should exist. In other words, why did such a phenomenal process of colonization occur, ultimately extending over half way around the world, and what major stimuli or constraints came to bear upon its regional expressions? These are important questions which will be considered from different viewpoints spanning various time-depths in some of the chapters which follow. There may be no simple answers, but the questions are worthy of articulation and asking.

\section{Comparative Methods in Linguistics and Anthropology}

All Austronesian languages are currently considered to derive from a single parent language, probably spoken on Taiwan something over 5000 years ago. Many scholars consider that the Austronesian language family has four highest order subgroups. Three of these subgroups comprise languages confined to Taiwan. The fourth subgroup - Malayo-Polynesian — includes all of the Austronesian languages spoken outside Taiwan. In effect, therefore, it is this 
subgroup of Austronesian languages that constitutes the predominant focus of this volume.

The principal method used for subgrouping the Austronesian languages is the classical comparative-historical method, largely developed in the comparative study of the Indo-European languages. This method is based on the systematic comparison of regular sound correspondences between languages as a first step towards reconstructing a proto-language from which it is possible to trace the derivation of daughter languages. Once the reconstruction of a proto-language is achieved, individual languages and sets of languages can be examined to determine the innovations they reflect relative to the proto-language. It is essentially upon shared innovations (phonological, morphosyntactic and lexical) between languages and sets of languages that subgroupings are established. Although the existence of the related Austronesian languages was already recognized in the seventeenth century, the systematic comparative research of Otto Dempwolff (1934-38) laid the foundations for much present-day linguistic research.

Comparative approaches to the study of the Austronesians in anthropology have been far more varied. Different regionally focused efforts at comparison have contributed to Austronesian studies and gradually the various separate strands of this research have begun to coalesce in a common set of comparative interests and approaches. L.H. Morgan's investigation of Hawaiian kinship and his construction of a "punaluan" family (1870) could be considered an early contributor to this research, as could W.H.R. Rivers' history of Melanesian society (1914). F. Eggan's research on the Philippines which, in part, led to his paper on the method of controlled comparison (1954); the work of W.H. Goodenough in Micronesia that provided a basis for his influential paper on Malayo-Polynesian social organization (1955); Sahlins' investigation of social stratification in Polynesia (1958) and I. Goldman's comparative study of status systems in ancient Polynesia (1970) all contributed to common comparative concerns.

Another important strand in this comparative mix was the work of Dutch anthropologists in Indonesia. In 1935, at a time when Dempwolff was in the midst of publishing his Austronesian research, the Leiden anthropologist, J.P.B. de Josselin de Jong, delivered a programmatic call for the comparative study of populations of Indonesia. Inspired not by linguistic investigations but by Radcliffe-Brown's study of "The Social Organization of Australian Tribes" (1931), de Josselin de Jong's "The Malay Archipelago as a Field of Ethnological Study" $(1935,1977)$ set in train a program of research that has, under various guises, continued to this day.

The single most influential comparative study to draw on J.P.B de Josselin de Jong's inspiration was that of his student, F.A.E. van Wouden, whose 
investigation of the societies of eastern Indonesia $(1935,1968)$ attempted to identify certain structural features of these societies as developments from an earlier proto-form of social organization - an organization that resembled Radcliffe-Brown's model for Australia. Other Dutch anthropologists, including van Wouden himself at a later stage in his career, allowed this comparative approach to inform their ethnographic researches without committing themselves too rigidly to a single prototypic model of society. Later reformulations of this "Ethnological Field of Study" approach continued to insist on investigation of a shared "structural core" (P.E. de Josselin de Jong 1980, 1984), but also called for a linguistic focus directed to the study of a common set of shared social categories - the continuing preservation of similar metaphors for living (Fox 1980). A similar emphasis on the study of "historical metaphor" and its comparative significance was articulated and developed by Sahlins in his study of Hawaii and of the other Pacific island societies (1981, 1985). One evident inspiration for these perspectives was the work of the Indo-European comparativist, George Dumézil.

More explicitly in relation to the study of Indonesian societies, however, both Fox $(1980,1988)$ and Blust (1984) argued that to preserve the notion of an Ethnological Field of Study required reinterpreting it in relation to, and as part of, the comparative study of Austronesian languages. This notion was particularly critical in comparisons between Austronesian and non-Austronesian societies in areas, such as Halmahera, where contact has been continuous for periods of several millennia (Platenkamp 1984; Bellwood 1994).

The Comparative Austronesian Project under whose auspices this volume took shape was intended to draw together anthropological, archaeological and linguistic approaches for the study of the Austronesian-speaking populations and to fashion a general framework for the mutual interpretation of the complexities of the Austronesian heritage. The disciplines drawn upon to illuminate this heritage include some which focus mainly on the comparative analysis of phenomena of the present or the recent ethnographic past; these disciplines include linguistics, social anthropology, genetics and zoogeography. Cross-cutting are other disciplines which draw their data directly out of traces of humanity and human activity which survive from the remoter past. These disciplines include archaeology, palaeoanthropology and literary history.

The chapters have been organized into two sections, the first focusing on questions of origins and dispersal, the second on questions of the interactions and transformations which Austronesian peoples and societies have undergone since dispersal occurred. 


\section{Origins and Dispersals}

The three initial chapters in the volume examine the linguistic evidence for Austronesian origins and dispersal. Tryon gives an overview of the Austronesian language family and examines the evidence for current higher level Austronesian subgrouping hypotheses and the methodology employed in comparative-historical linguistics. Pawley and Ross examine the huge Oceanic subgroup of Austronesian, of which roughly half of all Austronesian languages are members. They give an account of the culture history of the Oceanic subgroup and discuss the dispersal of the constituent languages through Melanesia and across the Pacific, looking into the question of why some Oceanic languages have changed more than other Austronesian languages. Adelaar's paper discusses the pivotal role of Borneo in terms of the original homeland and subsequent dispersal of some of the major Austronesian languages, especially Malagasy, the Malayic subgroup, the Tamanic and the Land Dayak languages.

The next three chapters deal with the archaeological record for early Austronesian dispersal. Bellwood examines questions of the ultimate homeland region for the Austronesians in southern China and Taiwan, regarding the Austronesians as a population, like many other major ethnolinguistic groups in the agricultural latitudes of the world, who began their expansion as a result of an early adoption of agriculture in a world predominantly populated by hunter-gatherers. He continues with an examination of possible reasons for the success and remarkable extent of the dispersal (reasons which clearly extended beyond a simple reliance on agriculture) and raises a number of issues about some of the early transformations which occurred as Austronesian colonists moved into new social and environmental landscapes.

The chapter by Spriggs then examines the archaeological evidence for the colonization of the Pacific Islands, focusing on the Lapita culture starting around 3500 years ago and discussing its relevance for the ancestry of the Melanesians, Micronesians and Polynesians. The Austronesians were not, of course, the first settlers of the western Pacific and they certainly did not colonize uncontested space; some of the results of the ensuing interactions are also discussed by Spriggs, as is some of the recent genetic evidence which is now becoming so important in any discussion of the origins of the actual people of the Austronesian world.

The early Austronesians were also advantaged in possessing an excellent sailing technology. Horridge, in his contribution to the volume, examines this Austronesian sailing technology and identifies its chief features. He concludes that early Austronesian sailing vessels consisted of a lashed-lug construction of sewn planks on a hollowed-out log base with a single outrigger and a triangular sail pushed up by a tilting pole. The nature of this sail and the way the vessel was steered made it a kind of early windsurfing craft. As Horridge makes clear, 
this windsurfing craft favoured sailing into the wind with a later downwind return.

In the final chapter in this section on origins and dispersal, Groves discusses the ancestors and origin regions for some of the major domestic animals of the Austronesians (water buffalo, cattle, pig and dog) and also some of the small commensal species which travelled with them. Except for Bali cattle and possibly pigs, the species discussed were all introduced into the Austronesian world from mainland Asia. Questions arise of when and how they were introduced and Groves also raises the important observation that some might ultimately have Indian homelands, a source which does not tie in well with geographical reconstructions of Austronesian prehistory prior to about 2000 years ago. The archaeological record for the species discussed, so far not a topic given much attention in the island regions of Southeast Asia, will doubtless have much to contribute to our knowledge of Austronesian dispersal in the future.

\section{Historical Interactions and Transformations}

The evidence of comparative linguistics and of archaeology for the historical origin and spread of Austronesian-speaking peoples is so overwhelming in its general conclusions that most research in other disciplines has shifted to ask more specific questions. These questions concern the transformations that occurred as a result of this spread of the Austronesians - both the internal developments within individual Austronesian cultures as well as those developments that resulted from contact among Austronesian groups and with other populations and cultures. Neither the biology, the language nor the culture of the Austronesians has remained static over the past 5000 years. It is these historical developments that the papers in the second section of this volume address.

Serjeantson and Gao, for example, in their paper argue for an evolutionary perspective that clearly recognizes the biological changes that have occurred. They focus on the evolutionary forces that have effected changes in the genetic make-up of the populations of Oceania. Whereas the Polynesians share many genetic features with Island Southeast Asians, they have also acquired genes from Melanesian populations and, importantly, have undergone further evolution, losing certain genes, in their migrations into the Pacific. The result is a genetic repertoire that is certainly different from that of the earliest Austronesians.

The Serjeantson and Gao paper also addresses a key question raised about the early Austronesians. Otto Dempwolff, who was one of the founding figures in the development of comparative Austronesian linguistics, served for a long period as a medical doctor in what was, at the time, German New Guinea. In 1904, following an earlier suggestion by another German doctor, Danneil, 
Dempwolff speculated that malaria may have exerted a significant selective pressure on early Austronesian populations whereas the non-Austronesian populations had, it appeared, developed a degree of immunity that gave them a selective advantage in highly malarial areas. By this argument, it was the islands with the least malaria that provided the safest pathway for the spread of the early Austronesians. Based on extensive research reported in Serjeantson et al. (1992), the Serjeantson and Gao paper lends support to Dempwolff's idea suggesting that the early Austronesians may indeed have arrived in Melanesia to find a malarial region inhabited by peoples comparatively well adapted to the environment and therefore it would have been prudent for them to have kept to the small islands and to have continued eastward.

The paper by Bhatia, Easteal and Kirk makes similar observations in examining the different genetic make-up of Austronesian- and non-Austronesian-(or Papuan)-speaking populations within Melanesia. Based on earlier research, Kirk has identified three patterns of linguistic and genetic differentiation based on unique allele combinations: 1) an Australoid pattern that relates to the Aboriginal populations of Australia, 2) a proto-Papuan pattern whose highest frequencies occur in the highlands of Papua New Guinea and parts of Irian Jaya, with lower frequencies along the New Guinea coast and still lower frequencies in the Solomons, Banks Islands and Polynesian Outliers, and, 3) an Austronesian pattern that is not found in Australia and rarely occurs in the Papua New Guinea Highlands. The highest frequency of this pattern is to be found in some coastal areas of north and east New Guinea, the Solomons, Banks Islands, the western Carolines and Fiji. Bhatia, Easteal and Kirk show that while language may be an indicator of genetic difference in broad geographical terms, in Melanesia it is not an adequate discriminant in specific cases.

Dutton's chapter points towards a similar conclusion. He examines the types of contact-induced change which have been observed in the Austronesian languages of Melanesia and discusses the problems posed by such change for the classification of the languages of the Oceanic subgroup of Austronesian. The complex relationships between the Austronesian- and non-Austronesian-speakers, particularly in eastern Indonesia and Melanesia where contact has had such a long history, raises fundamental questions for the study of the cultures of the region.

The past poses questions as well as providing answers. Based on the linguistic and archaeological knowledge of Austronesian expansion, the anthropological contributions to this volume consider various questions regarding the structure and distribution of contemporary Austronesian communities.

Fox looks at the diversity of Austronesian societies and the proliferation of technical terms that have been used by observers to describe these societies. In the face of these diverse descriptive appellations, he focuses on a number of 
common features among virtually all Austronesian societies: the concern with the tracing of local origins and the reliance on a variety of narratives for the construction of a shared past. Thus the sharing of a journey may be used to define relatedness whereas claims to precedence, often based on the order of events in particular narratives, figure prominently as means of defining social differences.

The paper considers two formal models of social differentiation among Austronesian societies, the one involving a process of "lateral expansion", the hiving-off of groups of relatively equal status to form new groups and the other involving a process of "apical demotion" among differentiated segments of society, often combined with a concomitant expulsion of high ranking segments to form new groups or opponent factions within society. Fox suggests that these two systems of differentiation rely on different structured narratives of the past to base their construction of origins and their determination of precedence. Thus, for example, in systems of lateral expansion, one encounters what Fox refers to as "spatialization of time" in origin narratives.

Sather in his paper addresses a number of questions that relate to Austronesian-speaking sea nomads and rainforest hunter-gatherers. If, as the linguistic and archaeological evidence indicates, the early Austronesians had developed, in addition to their sailing technology, the capacity to cultivate both rice and millet and, as they expanded, adopted a repertoire of other cultivated plants, such as banana and sugar cane, yams and taro, then certainly those contemporary Austronesian cultures without cultivation cannot be seen as exemplars of a prototypical Austronesian society.

Sather's examination of the case of the Sama-Bajau, who are a widespread group of nomadic fishing people, is particularly instructive. Instead of looking at Sama-Bajau sea nomads as a single distinguishable population, he considers all the Sama-speaking populations, both settled and nomadic, as a group of related peoples whose languages can be traced to a proto-form that existed in the first millennium AD. Linguistic reconstructions for proto-Sama indicate a familiarity with farming, pottery-making, weaving and even iron-forging. Although predominantly oriented to the sea, present-day Sama-speakers show a range of adaptations to land and sea. These groups include farmers as well as fishermen and traders. In fact, within this larger group, nomadic boat populations are a small minority whose way of life represents a particular historical adaptation to expanding maritime trade. Thus Sather suggests that the early Austronesians, like the early Sama populations, had a diverse economy based on both foraging and farming, hunting and horticulture which over time led to different local adaptations.

Thomas also develops a set of contrasting models to consider patterns of exchange in Oceania. One form of exchange involves the giving of like-for-like, 
emphasizing the quantity of goods that are exchanged, particularly the competitive exchange of food among localized regionally undifferentiated groups; the other form of exchange involves the giving of dissimilar valuables among regionally extensive and differentiated groups organized on a hierarchical basis. Thomas then illustrates the working of such models both historically and regionally in Oceania.

Differing forms of exchange, the "directionality" of exchange, the "gendering" of exchange goods, and the differential value of women in exchange have been major foci of discussion in the Austronesian literature. This is particularly true of the anthropological literature on eastern Indonesia since the time of F.A.E. van Wouden, whose dissertation made the exchange systems of the region a critical focus of his analysis. Thomas's paper is of direct comparative relevance to these continuing Austronesian research concerns.

The concluding papers in this volume examine the ways in which Austronesian societies have adapted to outside influences, particularly those of the world religions - first, Hinduism and Buddhism and then Islam and Christianity. Supomo looks at the earliest Indian contacts with Indonesian societies and the changes in religious and political organization that this brought about, particularly the dissemination of literacy that eventually led to an indigenous adaptation and transformation of Indian literary works, such as the Mahābhārata and the Rāmāya a. Inscriptions in Sanskrit gave way to a number of inscriptions in Old Malay during the time of Śrīwijaya (late 7th century AD) and to a proliferation of inscriptions in Old Javanese that lasted for a period of six centuries beginning in AD 804. These early inscriptions provide some of the oldest examples of Austronesian languages preserved for examination. The Javanese inscriptions and later literary works, which Supomo refers to as "temples of language" as opposed to "temples of stone", offer glimpses of social life defined by recognizable Austronesian categories.

Supomo notes that Old Javanese inscriptions refer to local indigenous communities as wanua [PMP *banua] and their inhabitants as anak wanua. The councils that governed these communities consisted of elders referred to as rama [PAn *ama meaning 'father']. Wanua were grouped in territorial units referred to as watak and these watak, in turn, were headed by rakai, a designation which Supomo argues is derived from the term for 'elder' or 'grandfather' [PAn *aki]. This early Javanese political system was presided over by a figure given the title ratu [PMP *datu, meaning 'ancestor, chief, lord'].

The system utilizes a recognizable kinship idiom which can be related both to proto-Austronesian and to contemporary Javanese. Using the evidence from Old Javanese texts, Fox has shown that earlier Javanese kinship is entirely Austronesian in structure with little Sanskrit influence. Indeed the semantic structure of modern Javanese kinship gives evidence of a clear continuity and 
development from Old Javanese (Fox 1986). As Supomo points out, one must look to Bali even more than Java for many of the continuities with older Javanese traditions because the "temples of language" which he describes were transported and transplanted there after the coming of Islam. It is interesting therefore to note that local communities organized in terms of banua and presided over by village councils still continue to function in the upland areas of Bali today (Reuter, pers.comm. 1994).

Like Supomo, Reid also examines the continuities and changes that occurred in response to outside religious and political influences - the coming of Islam and then Christianity among the maritime populations of Southeast Asia from the fifteenth century onward. These sailing and trading populations included Malays, Javanese, Chams and Tagalogs ("Luzons") who had long-standing historical relationships with one another and with the populations of the hinterlands for whom they provided an opening to the sea. The new religions brought about rapid changes in matters of identity - dress, speech, deportment and diet - as well as more gradual but profound changes in sexual morality, in the ritual role of women, and in relationships to the sacred, including attitudes toward the spirit world and the dead.

Yengoyan's paper continues this theme in examining the diverse ways in which Christianity, promulgated through different colonial institutions and cultures, has transformed the cultures of the Philippines and the Pacific. In this transformation of local Austronesian societies, instead of fostering any one particular form of society, the combination of western colonialism and Christianity has proffered a concept of individuality, stressing the roles, rights and responsibilities of individuals in all social relationships. It is this concept that continues to exert a profound effect on Austronesian societies throughout the region.

The papers published here were all presented initially during a three-day conference entitled “The Austronesians in History: Common Origins and Diverse Transformations", held in the Coombs Lecture Theatre in the Australian National University in November 1990. The conference was organized under the auspices of the Comparative Austronesian Project in the Research School of Pacific Studies at ANU. In accord with the aims of this project the papers were requested to be on a broad scale - comparative, interdisciplinary and historical in orientation. The results provide a survey of some of the most significant facets of the Austronesian trajectory through time and space, although as with all books of this kind there are obviously some gaps.

It is worthy of note that this volume falls into a tradition of multi-disciplinary works on the histories of the various major language families of the world. Previously, such volumes have tended to stress archaeological and linguistic information at the expense of other sources, often because they have explicitly 
researched the interfaces between these two disciplines (e.g. Ehret and Posnansky 1982 for Africa; Renfrew 1987, Mallory 1989, Markey and Greppin 1990 for Indo-European). It is apparent that such volumes have the potential to generate broad comparative debate. Hopefully, this volume on the Austronesians will do the same, particularly with its broadening of the disciplinary input to include anthropology, biology and documentary history. Austronesia today includes many highly significant developing nations; an understanding of its historical raison d'être must be seen as an important goal, both for research and for education, by and for Austronesians and non-Austronesians alike.

\section{References}

Allen, J. and P. White

1989 The Lapita homeland: some new data and an interpretation. Journal of the Polynesian Society 98:129-146.

Bellwood, P.

1994 The archaeology of Papuan and Austronesian prehistory in the Northern Moluccas, Eastern Indonesia. Paper given at the World Archaeological Congress, New Delhi, 4-11 December.

Blust, R.A.

1984 Indonesia as a "field of linguistic study". In P.E. de Josselin de Jong (ed.) Unity in diversity: Indonesia as a field of anthropological study, pp.2137. Verhandelingen van het Koninklijk Instituut voor Taal-, Land- en Volkenkunde 103. Dordrecht: Foris Publications.

Dempwolff, Otto

1904 Über aussterbende Völker. Die Eingeborenen der "Westlichen Inseln" in Deutsch-Neu-Guinea. Zeitschrift für Ethnologie 36:414.

1934-38 Vergleichende Lautlehre des austronesischen Wortschatzes. 3 vols. Berlin: Reimer.

Eggan, Fred

1954 Social anthropology in the method of controlled comparison. American Anthropologist 56:743-763.

Ehret, C. and M. Posnansky (eds)

1982 The archaeological and linguistic reconstruction of African history. Berkeley: University of California Press.

Flannery, K.V. and J. Marcus (eds)

1983 The cloud people. New York: Academic Press.

Fox, J.J. 
1980 Models and metaphors: comparative research in Eastern Indonesia. In J.J. Fox (ed.) The flow of life: essays on Eastern Indonesia, pp.327-333. Cambridge, Mass.: Harvard University Press.

1986 The ordering of generations: change and continuity in old Javanese kinship. In D.G. Marr and A.C. Milner (eds) Southeast Asia in the 9th to 14th centuries, pp.315-326. Singapore: Institute of Southeast Asian Studies and Canberra: Research School of Pacific Studies, The Australian National University.

1988 Review of P.E. de Josselin de Jong (ed.) Unity in diversity: Indonesia as a field of anthropological study. Verhandelingen van het Koninklijk Instituut voor Taal-, Land- en Volkenkunde 144(1):178-181. Dordrecht: Foris Publications.

Goldman, I.

1970 Ancient Polynesian society. Chicago: University of Chicago Press. Goodenough, Ward H.

1955 A problem of Malayo-Polynesian social organization. American Anthropologist 57:71-83.

Houghton, $\mathrm{P}$.

1991 The early human biology of the Pacific: some considerations. Journal of the Polynesian Society 100:167-196.

Josselin de Jong, J.P.B. de

1977 The Malay Archipelago as a field of ethnological study. In P.E. de Josselin de Jong (ed.) Structural anthropology in the Netherlands: a reader, pp.164182. The Hague: Martinus Nijhoff. (Originally published in 1935 as "De Maleische Archipel als ethnologisch studieveld". Leiden: Ginsberg.)

Josselin de Jong, P.E. de

1980 The concept of the field of ethnological study. In J.J. Fox (ed.) The flow of life: essays on Eastern Indonesia, pp.317-326. Cambridge, Mass.: Harvard University Press.

1984 A field of anthropological study in transformation. In P.E. de Josselin de Jong (ed.) Unity in diversity: Indonesia as a field of anthropological study, pp.1-10. Verhandelingen van het Koninklijk Instituut voor Taal, Land- en Volkenkunde 103. Dordrecht: Foris Publications.

Kirch, P.V. and R.C. Green

1987 History, phylogeny and evolution in Polynesia. Current Anthropology 28:431-456.

Mallory, J.P. 
1989 In search of the Indo-Europeans. London: Thames and Hudson.

Markey, T.L. and J.A.C. Greppin (eds)

1990 When worlds collide. Ann Arbor: Karoma.

Moore, J.H.

1994 Putting anthropology back together again: the ethnogenetic critique of cladistic theory. American Anthropologist 96(4).

Morgan, Lewis Henry

1870 Systems of consanguinity and affinity of the human family. Smithsonian Contributions to Knowledge 218. Photomechanic reprint after the edition of 1871. Washington: Smithsonian Institution.

Peoples, J.G.

1993 Political evolution in Micronesia. Ethnology 32:1-18.

Platenkamp, J.D.M.

1984 The Tobelo of Eastern Halmahera in the context of the field of anthropological study. In P.E. de Josselin de Jong (ed.) Unity in diversity: Indonesia as a field of anthropological study, pp.167-189. Verhandelingen van het Koninklijk Instituut voor Taal-, Land- en Volkenkunde 103. Dordrecht: Foris Publications.

Radcliffe-Brown, A.R.

1931 The social organization of Australian tribes. Oceania 1:34-63, 206-246, 322-341, 426-456.

Renfrew, C.

1987 Archaeology and language. London: Jonathan Cape.

Rivers, W.H.R.

1914 The history of Melanesian society. Cambridge: The University Press.

Romney, A.K.

1957 The genetic model and Uto-Aztecan time perspective. Davidson Journal of Anthropology 3:35-41.

Sahlins, M.D.

1958 Social stratification in Polynesia. Seattle: University of Washington Press.

1981 Historical metaphors and mythical realities: structure in the early history of the Sandwich Islands kingdom. Association for the Study of Anthropology in Oceania, Special Publication No. 1. Ann Arbor: University of Michigan Press.

1985 Islands of history. Chicago: University of Chicago Press. 
Serjeantson, S.W., P.G. Board and K.K. Bhatia

1992 Population genetics in Papua New Guinea: a perspective on human evolution. In R.D. Attenborough and M.P. Alpers (eds) Human biology in Papua New Guinea: the small cosmos, pp.198-233. Oxford: Clarendon Press.

Terrell, J.

1981 Linguistics and the peopling of the Pacific Islands. Journal of the Polynesian Society 90:225-258.

1986 Prehistory in the Pacific Islands. Cambridge: Cambridge University Press.

Wouden, F.A.E. van

1968 Types of social structure in Eastern Indonesia. The Hague: Martinus Nijhoff. Koninklijk Instituut voor Taal-, Land- en Volkenkunde, Translation Series 11. [Originally published in Dutch in 1935.]

\section{Notes}

1 The principal opponents of the view that Austronesian language distributions reflect human colonization are drawn not from linguistics, but from archaeology and biological anthropology. For instance, a number of Oceanic specialists in these two disciplines believe that the Austronesian-speaking populations of Polynesia and Melanesia are drawn entirely from a western Melanesian ancestry spanning the past 30,000 years (Allen and White 1989; Terrell 1981, 1986; Houghton 1991), and have never shared any significant degree of common origin with the peoples of Island Southeast Asia, except at the time of initial settlement in the Pleistocene. These opinions either ignore languages entirely, or explain the situation according to linguistic models which utilize data sets of restricted geographical and disciplinary significance. There is often a strong motivation to assert theoretical positions centred entirely on views of in situ diversification. For instance, according to Terrell (1981:235):

2 ... resemblances between Asians and Austronesian speakers in Oceania that have been proposed are either suspect in themselves, or equally attributable to chance correspondences rather than common descent.

Such a view tends to overlook the complexity of past and present humanity in Southeast Asia, as though the narrow sea gaps immediately west of New Guinea marked an eternal barrier to all humans except, paradoxically, the first sea-borne migrants of 50,000 years ago. If the latter could move with ease from Indonesia into Australasia, why not also the navigationally better equipped Austronesians of the past 4000 years?

The general concept of the genetic (or phylogenetic) unit has also been applied to situations of cultural diversification in other parts of the world, e.g. Flannery and Marcus (1983) for Otomanguean-speaking populations in Mesoamerica, and Romney (1957) for Uto-Aztecans. Peoples (1993) has recently applied the concept to Micronesia. Classic anthropological applications of the idea to Polynesia have been those of Sahlins (1958) and Goldman (1970). 